\title{
Modeling Streamflows and Flood Delineation of the 2004 Flood Disaster, Mānoa, $\mathrm{O}^{‘} \mathrm{ahu}$, Hawai $^{\prime} \mathbf{i}^{1}$
}

\author{
Aly I. El-Kadi ${ }^{2,3}$ and Eric Yamashita ${ }^{4}$
}

\begin{abstract}
In October 2004 a flood caused extensive damage to the University of Hawai'i (UH) campus and neighboring residential areas in Mānoa Valley, O'ahu, Hawai'i. This modeling study was aimed at streamflow evaluation and flood delineation for the area impacted by the flood. The study concluded that the HEC-1 model of the U.S. Army Corps of Engineers is suitable for simulating storm runoff response for the study area, considering the nature of small Hawai' $i$ watersheds, which generate hydrographs with steep rising and falling limbs. The curve-number method of the U.S. Soil Conservation Service is also suitable because it predicts reasonably well the main features of streamflow hydrographs, including runoff duration and time of peaks. To improve on accuracy, however, there is a need for better characterization of spatial rainfall distribution through measurements. A flood delineation model, which treats the flood as a hypothetical dam break, was used to predict the floodwater pathway, flood zone extent, maximum flood depth, and the time to reach that depth. The model predicted an upper value for storm total flow volume that would not cause flooding on the UH campus. Although not fully validated, the developed models can guide data-collection and decision-making processes. For example, the models demonstrated that it is possible to mitigate the flood through streamflow diversion and stream dredging, realignment, and lining. For efficient management, we recommend defining a new subwatershed of the Ala Wai basin (to be called the West Mānoa Watershed) that contains the university campus.
\end{abstract}

HawaI'I's CLimate is characterized by high rainfall rates. However, due to the high permeability of the rocks and soils, most streams do not flow continuously throughout the year (U.S. Army Corps of Engineers 1998). On the other hand, the steep slope nature of

${ }^{1}$ This is contributed paper CP-2007-01 of the Water Resources Research Center, University of Hawaici at Mānoa, Honolulu. Manuscript accepted 8 June 2006.

${ }^{2}$ Corresponding author.

${ }^{3}$ Department of Geology and Geophysics and Water Resources Research Center, 1680 East-West Road, University of Hawai'i at Mānoa, Honolulu, Hawai'i 96822 (phone: 808-956-6331; fax: 808-956-5512; e-mail: elkadi@hawaii.edu).

${ }^{4}$ Office of the Vice Chancellor of Administration, $\mathrm{Fi}_{-}$ nance, and Operations, University of Hawai'i at Mānoa, Honolulu, Hawai'i 96822.

Pacific Science (2007), vol. 61, no. 2:235-255

(C) 2007 by University of Hawai'i Press

All rights reserved watersheds in Hawai' $i$ creates conditions of high peak flows with a sharp rise and recession, increasing the chance of flash floods occurring during storm events. More than 12 major floods have occurred in Mānoa Valley, O'ahu (see Figure 1), causing damage and fatalities in some cases (Hawai'i Department of Land and Natural Resources 1995). On 30 October 2004 the area received about 25 $\mathrm{cm}$ of rain in a 10-hr period. According to the National Weather Service Forecast Office, Honolulu, Hawai'i, the unstable atmosphere allowed showers to develop rapidly into a thunderstorm and remain focused over a small area of southeastern O'ahu (http://www.prh.noaa.gov/hnl/pages/events/ ManoaFlood20041030/). The thunderstorm was locked in place due to the terrain. At the height of the heavy rainfall, around 1900 hours, rainfall rates recorded by the gauge at the Lyon Arboretum, in the upper portion of Mānoa Valley, were over $12 \mathrm{~cm} / \mathrm{hr}$. Maximum rainfall accumulations at that site with 


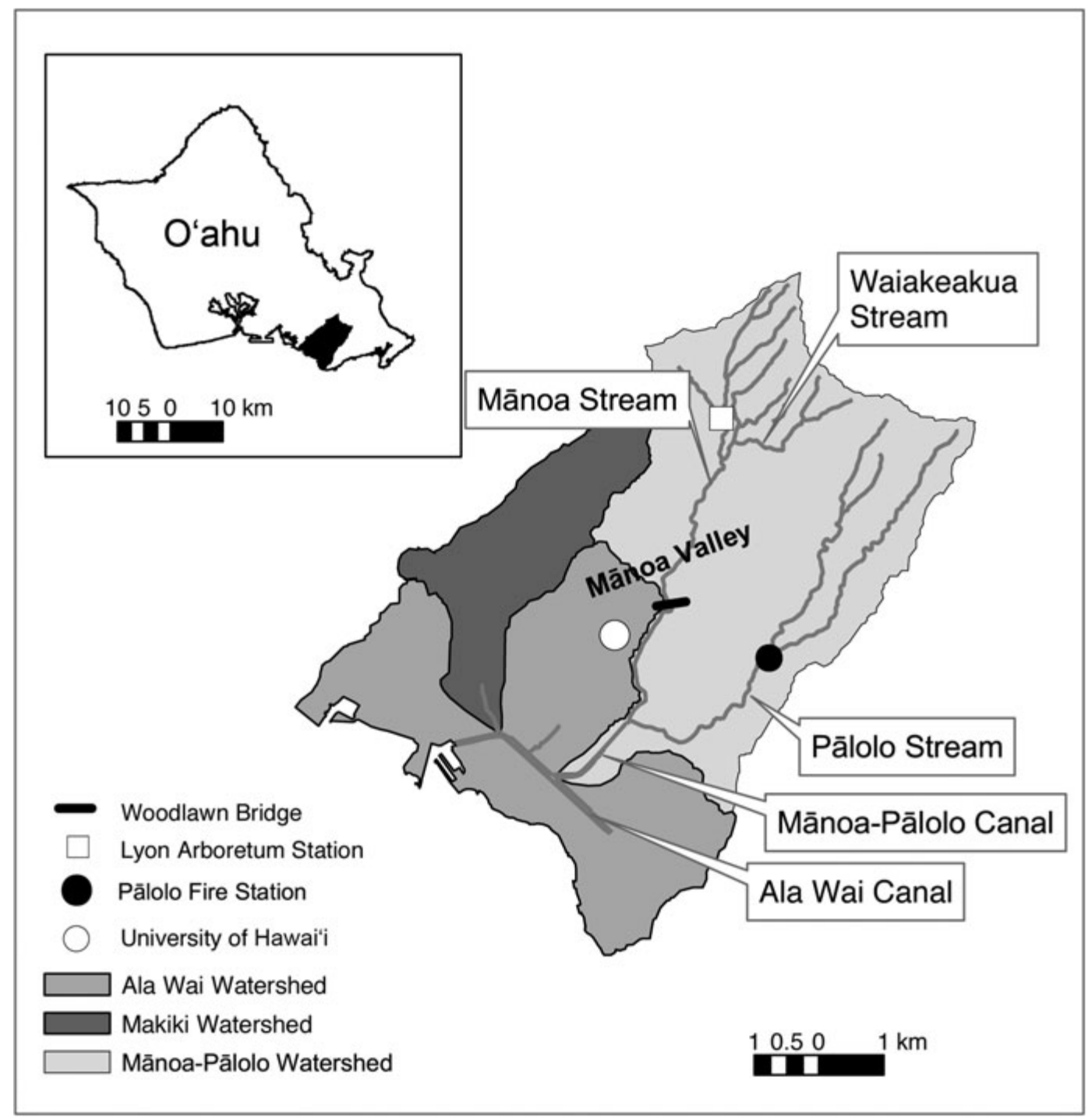

FIgURE 1. Location of the study area covering three watersheds on $\mathrm{O}^{\prime}$ ahu, Hawaici.

the respective times were $3.3 \mathrm{~cm}(15 \mathrm{~min})$, $9.4 \mathrm{~cm}(1 \mathrm{hr}), 11.1 \mathrm{~cm}(2 \mathrm{hr}), 14.5 \mathrm{~cm}(3 \mathrm{hr})$, and $22.1 \mathrm{~cm}(6 \mathrm{hr})$. These large rainfall rates are estimated to occur with a return rate of almost $50 \mathrm{yr}$. In other words, in any given year, there is only a $2 \%$ probability of such a heavy rainfall event like this occurring in upper Mānoa Valley.

The storm washed trees and debris into
Mānoa Stream, creating a dam under the Woodlawn Bridge. Floodwaters flowed onto the University of Hawai i (UH) campus (Figure 1), causing damage to buildings. Several Mānoa Valley neighborhoods also sustained damage.

Mānoa Stream floods are due to (1) an inadequate capacity of the natural stream channel to accommodate flood flows; (2) 
a relatively level terrain in some stream reaches, which slows down the flow of water; (3) restrictive bridge crossings; and (4) developments along the stream (Townscape, Inc., and Eugene P. Dashiell, AICP, in cooperation with Oceanit 2003). Studies of floods in the area include that by the Hawai'i Department of Land and Natural Resources (1995), which recommended increasing Mānoa Stream's capacity to $300-325 \mathrm{~m}^{3} / \mathrm{sec}$ to accommodate a $100-y r$ storm. That study also recommended implementing a yearly stream maintenance program for embankment areas, especially at bridge openings. For flood control, the study suggested widening and deepening the upstream and downstream approaches to some bridges to increase the capacity of the flow and establishing a linear park along some reaches to provide for floodplain management.

Although floods in the area are common, damage to the UH campus was not expected, considering that the campus area had not been identified as a flood-hazard zone. Thus it is of extreme importance to study the conditions that can cause such a situation. There is also a need to delineate new flood zones, which are essential for land and flood management in the Mānoa area.

Models are important tools for assessing hydrological conditions and for predicting system response to alterations based on management decisions. Flood delineation and mitigation decisions should be based on appropriate data collection and on sound scientific principles. For example, stream dredging can be efficient if depths and configurations are estimated through modeling. Models can guide data collection by emphasizing factors of high impact on the watershed's response to rainstorm events. They are also beneficial in assessing suitability of decisions addressing various flood mitigation strategies.

The objective of this study was to develop models for streamflows and for flood delineations in the Mānoa area. Suitability of the models for hydrological conditions at this site was examined. The study was also aimed at defining deficiencies in data and providing recommendations for future actions that can eliminate or reduce flood damage.
MATERIALS AND METHODS

\section{Study Site}

The greater Ala Wai watershed comprises three watersheds that lie on the southern slope of the Ko'olau Volcano (Figure 1), namely the Makiki, Mānoa-Pālolo, and Ala Wai Watersheds. The land area of the watersheds covers over $50 \mathrm{~km}^{2}$, and the altitude ranges from sea level to $900 \mathrm{~m}$. Most of the Honolulu volcanic flows that created this area are about 100,000 yr old. The lava flows created relatively flat floors in valleys such as Mānoa.

The three watersheds drain into the Ala Wai Canal, which is located on the southern shore of the island of $\mathrm{O}^{\prime}$ ahu, Hawai'i (Figure 1 [Hawai'i Department of Land and Natural Resources 1995]). Mānoa and Pālolo are lumped into one watershed because both Mānoa Stream and Pālolo Stream feed into the Mānoa-Pālolo drainage canal (Figure 1). The 2-km-long canal was created in 1935 to combine the flow of several meandering streams into one straight outlet to the ocean. The main reach of Mānoa Stream runs for approximately $5.6 \mathrm{~km}$-from the top of an urban area down to the Pālolo junction. Most of its tributaries, including Waiakeakua Stream, lie within a state conservation district.

Rainfall quantities in the area vary, with the upper portions of the mountains receiving an average of more than $400 \mathrm{~cm} / \mathrm{yr}$ and the lower portions receiving an average of less than $63 \mathrm{~cm} / \mathrm{yr}$ (Hawaili Department of Land and Natural Resources 1992). Rain falls throughout the year but mostly during the winter months.

\section{Watershed Model}

Detailed continuous watershed models that account for soil moisture storage are the most accurate for watershed assessment. However, the lack of input data limits the use of such models. For water hydrograph estimation we used the HEC-1 model within the Watershed Modeling System (WMS) (http://www.ems-i.com/WMS/wms 
.html). The Watershed Modeling System, a comprehensive environment for hydrologic analysis, was developed by the Environmental Modeling Research Laboratory of Brigham Young University in cooperation with the U.S. Army Corps of Engineers Waterways Experiment Station. The software provides interfaces to a number of hydrologic modeling programs, including HEC-1. In addition, the digital terrain modeling functions of the Watershed Modeling System can be used to create terrain models using geographic information systems data, triangulated irregular networks, or gridded digital elevation models. This information can then be used to delineate watersheds, streams, and subbasins. Once boundaries are created, geometric attributes such as area, slope, and runoff distances can be computed automatically. A topological tree representation of the watershed is then created, and all data necessary to define an HEC- 1 or other models can be entered by selecting basins and outlet points. The software package also contains the Simplified DamBreak model (Wetmore and Fread 1981), which is used in this study for flood zone delineation.

\section{Drainage Basins}

A gridded digital elevation model was used to delineate the watersheds and drainage pathways in the area (Figure 2). The data were based on the USGS 1:24,000 digital elevation model, which corresponds to $7.5-\mathrm{min}$ topographic quadrangle maps that cover about $10.1 \times 14.0 \mathrm{~km}$ at $10-\mathrm{m}$ resolution. The maps are cast to the Universal Transverse Mercator (UTM) projection system and are referenced to North American Datum of 1983 (NAD83). Drainage pathways can be delineated at different resolutions and can represent a generated or derived stream network. Drainage outlets can be designated on streams to divide the watershed into subareas. It should be noted that detailed subsurface water pathways to streams are not accounted for here due to simplicity of the watershed model used. However, overland flow should dominate stream runoff, especially during intense storm rain. Baseflow, which is impor- tant during dry weather, is simulated using a simplified approach that employs the initial flow in the stream, the flow at which recession begins on the receding limb of the hydrograph, and a decay rate.

In Figure 2, a new watershed, to be named the West Mānoa Watershed, is defined. With an approximate area of $16 \mathrm{~km}^{2}$, it covers a drainage area containing the $\mathrm{UH}$ campus. It should be noted that the generated boundary and streams for the Mānoa-Pālolo Watershed are almost identical to those shown in Figure 1. The West Mānoa Watershed does not contain perennial streams; the generated drainage pathways in Figure 2 represent likely conduits for floodwaters.

Geographic information system coverages were obtained from the State of Hawai'i's database. Figure $3 a$ illustrates ground elevations for the Mānoa-Pālolo and West Mānoa Watersheds. Very steep slopes of greater than $70 \%$ exist, indicating substantial potential for increased runoff. Based on soil types in the area, Figure $3 b$ shows soil ratings, mostly describing zones with low drainage and high potential for runoff. Figure $3 c$ illustrates land use and land cover in the area, which is dominated by urban or built-up lands.

\section{The HEC-1 Model}

HEC-1 is a lumped-parameter, single-event model that simulates the surface-runoff response of a river basin to precipitation (U.S. Army Corps of Engineers 1998). The model is widely used for such applications as assessing flood potential due to land-use changes (e.g., Smith and Bedient 1981), estimating sediment transport (e.g., Martín-Vide et al. 1999), analyzing climate change effects on flood frequencies (Muzik 2002), and examining effects of precipitation uncertainty on runoff modeling (Maskey et al. 2004).

The HEC-1 model represents a river basin as an interconnected system of hydrologic and hydraulic components, with each component modeling an aspect of the precipitationrunoff process within a portion of the basin, or within what is commonly referred to as a subbasin. A component may represent a sur- 


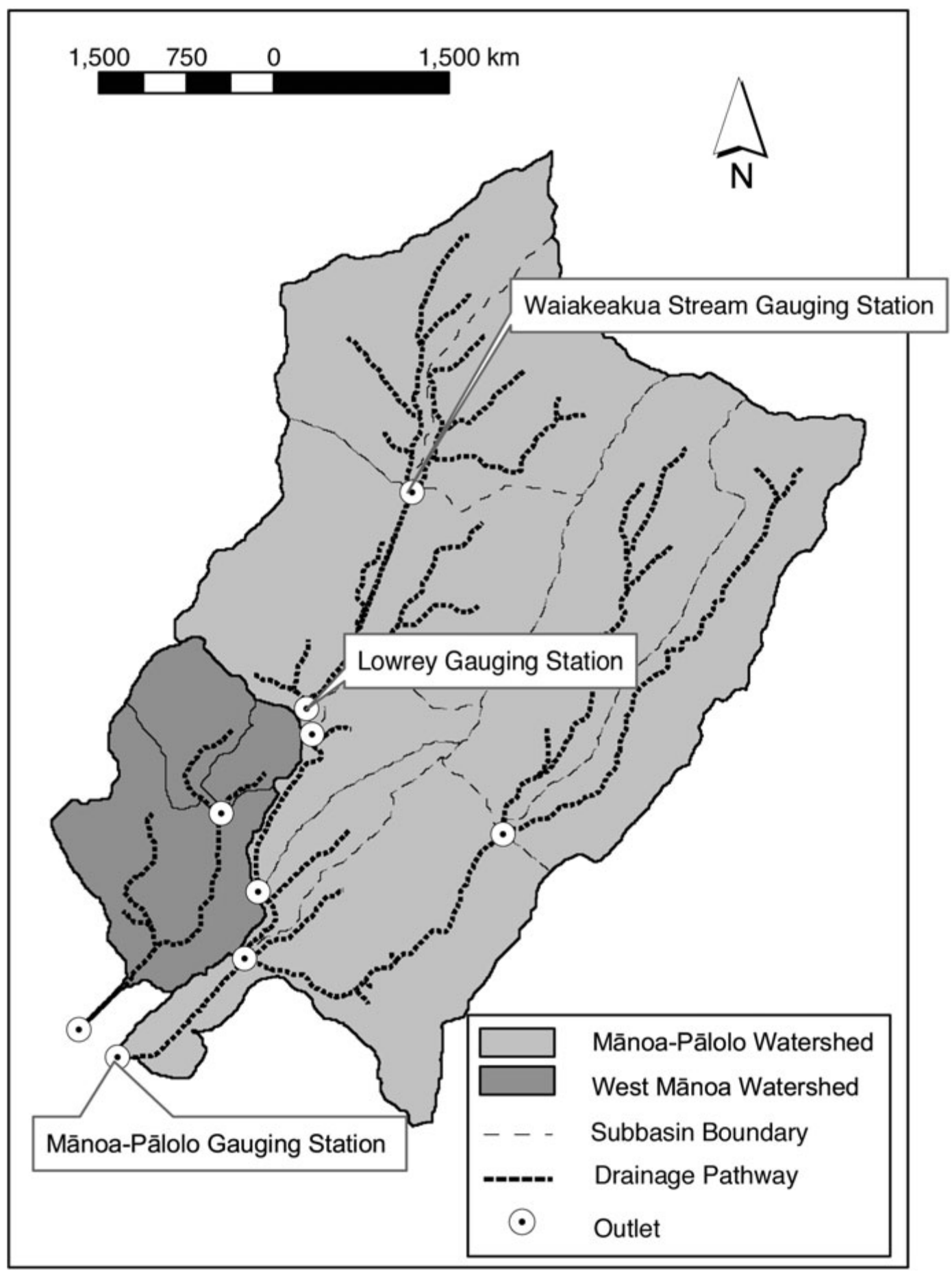

FIGURE 2. Delineated watersheds, subwatersheds, outlets, and drainage pathways in the study area. Locations of three gauging stations with available records are also shown. 

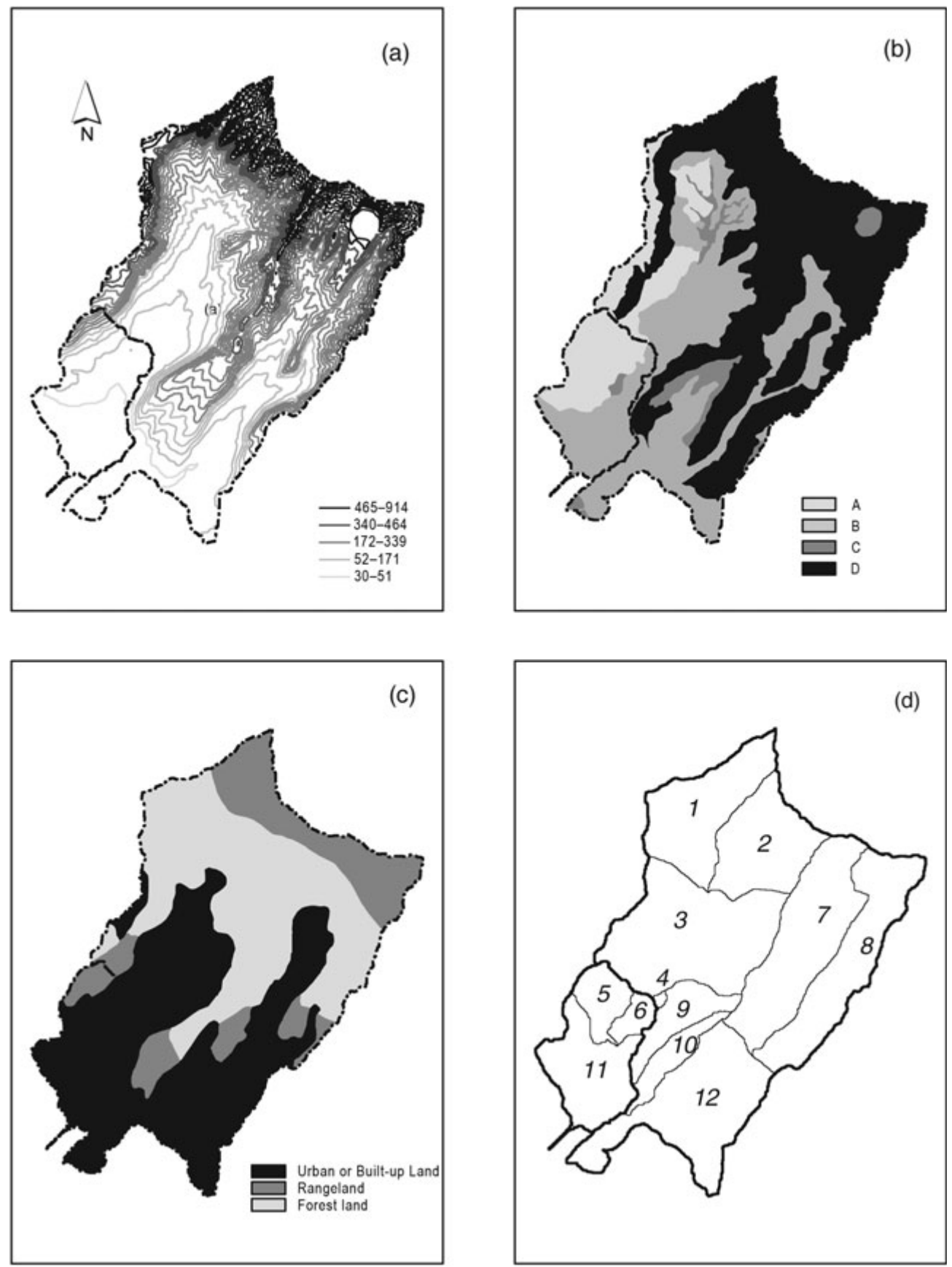

\section{$1,800900 \quad 0 \quad 1,800 \mathrm{~m}$}

FIgURE 3. Watershed information: $(a)$ ground elevation contours in meters, $(b)$ soil ratings (the potential for runoff increases with soil rating from A to D), (c) land use and land cover, and $(d)$ subbasin boundaries. 
TABLE 1

Pertinent Data for Various Subbasins Shown in Figure 3

\begin{tabular}{lccccc}
\hline \hline Subbasin & Area $\left(\mathrm{km}^{2}\right)$ & Average Slope & Lag Time $(\mathrm{hr})$ & Time of Concentration $(\mathrm{hr})$ & Curve Number \\
\hline 1 & 3.10 & 0.64 & 0.32 & 0.53 & 73 \\
2 & 2.76 & 0.70 & 0.26 & 0.43 & 76 \\
3 & 5.20 & 0.38 & 0.29 & 0.49 & 85 \\
4 & 5.05 & 0.04 & 0.10 & 0.17 & 79 \\
5 & 9.40 & 0.25 & 0.32 & 0.53 & 95 \\
6 & 4.44 & 0.06 & 0.29 & 0.48 & 79 \\
7 & 4.09 & 0.56 & 0.36 & 0.71 & 90 \\
8 & 3.51 & 0.59 & 0.43 & 0.48 & 74 \\
9 & 1.20 & 0.40 & 0.29 & 0.92 & 95 \\
10 & 8.05 & 0.24 & 0.55 & 0.85 & 96 \\
11 & 2.45 & 0.07 & 0.51 & 0.72 & 79 \\
12 & 4.36 & 0.17 & 0.43 & &
\end{tabular}

face-runoff entity, a stream channel, or a reservoir. Representation of a component requires a set of parameters specifying the particular characteristics of the component and mathematical relations describing the physical processes. Although not explicitly a distributed-parameter model, the model can be considered as such because it divides the basin into subbasins with variable basin characteristics. The result of the modeling process is the computation of streamflow hydrographs at desired outlets in the river basin.

As an event-based model, HEC-1 is designed to simulate hydrologic processes for short periods of time, starting at the onset of a rainfall event and ending shortly after the hydrograph recession returns to baseflow. Existing soil moisture before the event is not directly simulated by the model; rather, parameters are adjusted to reflect antecedent moisture conditions in the soil. Because the relationship between antecedent moisture conditions and model parameters is not well defined, such parameters are considered simply as fitting parameters.

The HEC-1 model was used to study an area covering the Mānoa-Pālolo and West Mānoa Watersheds (Figure 2). The Soil Conservation Service Unit Hydrograph Method (Soil Conservation Service 1972, 1975) was selected for use in all HEC-1 simulations. The area was divided into 12 subbasins, as shown in Figures 2 and $3 d$. Table 1 lists the respective areas and average slopes for each subbasin shown in Figure 3d. Curve numbers for each subbasin were determined using information from soil-type and landuse/cover maps. The lag time for each subbasin was calculated by applying the Soil Conservation Service method based on watershed length, Soil Conservation Service curve number, and average watershed slope.

A basin-average approach was used for rainfall data input to the model. With this method, the total precipitation amount for a subbasin is used in the simulation. Such an amount is combined with the time distribution of rainfall representing variation over the storm duration. Unfortunately, only two rain gauge stations (Lyon Arboretum and Pālolo Fire Station [Figure 1]) had complete rainfall records for the flood event. The total rainfall at the latter station was $5.4 \mathrm{~cm}$, compared with $25 \mathrm{~cm}$ at the former, signifying the great spatial variability of the storm. Based on the records for those stations and known average annual rainfall at other locations, average rainfall for the subbasin was estimated. The values were estimated based on interpolated values at the subbasin's centroid.

\section{Flood Zone and Levels}

The Federal Emergency Management Agency produces federal insurance rate maps that delineate areas within flood-inundation zones. 
Areas within 100-yr flood-hazard zones are generally associated with the urbanized portion of Mānoa Stream and the low-lying areas near the Ala Wai Canal. Several flood-control measures have been implemented along all three major streams in the Ala Wai Watershed.

The maps do not include flood-hazard zones within the West Mānoa Watershed. An objective of the paper is thus to delineate the 2004 flood zone in the West Mānoa Watershed using the HEC-1 simulated stream hydrograph discussed in the previous section. For flood delineation, we used the Simplified Dam-Break model developed by the National Weather Service (Wetmore and Fread 1981). The Simplified Dam-Break model is useful for situations where reconnaissance-level results are adequate and when data are lacking. Wurbs (1987) concluded that the Simplified Dam-Break model is an optimal choice for applications requiring expeditious analysis. An example application of the model for dam failure is given by Warner et al. (1996). The Simplified Dam-Break model is included within the Watershed Modeling System package, and its use is facilitated by the Watershed Modeling System interface.

The Simplified Dam-Break model approximates the downstream channel as a prism, including the effects of the off-channel (dead) storage, where appropriate. Only peak flows, maximum water-surface elevations, and travel times are considered. The program utilizes dimensionless peak-flow routing graphs developed by Fread (1988). Three steps make up the procedure used in the Simplified Dam-Break model: (1) calculation of the peak outflow at the dam using temporal and geometrical descriptions of the breach and the reservoir volume, (2) approximation of the channel downstream of the dam as a prismatic channel, and (3) calculation of dimensionless peak-flow routing parameters used with families of dimensionless routing curves to determine the peak flow at specified cross sections downstream of the dam. The input required for the model is thus a stream centerline, cross sections, and information regarding the storage capacity and failure of the dam. A digital elevation model for the site is the main input to the user interface, which generates all necessary geometrical data. The model output includes watersurface-elevation data that can be used for delineating the floodplain and estimating maximum flood depth and the time to reach such a depth.

The main parameters for the Simplified Dam-Break model are reservoir surface area at the maximum pool-level elevation, maximum pool-level elevation minus final breachbottom elevation (called "the head on the breach"), average final breach width, and time of failure. Default values in the model include the reservoir surface area, which is estimated at twice the reservoir volume divided by the dam height. The head on the breach is set equal to the height of the dam.

A point upstream of the Woodlawn Bridge was chosen as the location of the hypothetical dam failure because flooding in the area downstream of the bridge was a precursor to the West Mānoa 2004 flood. It is implicit here that the flooding was caused by both channel constrictions and the formation of the dam under the Woodlawn Bridge caused by trees and debris. For our study, the parameters listed here are merely fitting parameters, obviously considering that flooding is treated as a hypothetical dam failure. The results were most sensitive to the head on the breach. Trial and error was used to determine a minimum value to cause flooding of the banks of Mānoa Stream near the Woodlawn Bridge such that flooding, in turn, would occur in the West Mānoa Watershed. A value of $12.9 \mathrm{~m}$ provided reasonable results (i.e., the water level reached an equivalent dam head of $56 \mathrm{~m}$ [above mean sea level]). The simulation assumed a flood volume of $1.1 \times 10^{6} \mathrm{~m}^{3}$, which is based on the HEC- 1 simulations described in previous sections. In this case the surface area of the reservoir would be around $0.6 \mathrm{~km}^{2}$. The average final breach width was estimated at three times the height of the dam, which is about $34.4 \mathrm{~m}$ in this case. Based on these values, the flux near the dam was determined to be 2,370 $\mathrm{m}^{3} / \mathrm{sec}$, which, when incorporating the total volume of flow, would lead to an estimate of time for the hypothetical failure at $8 \mathrm{~min}$. 


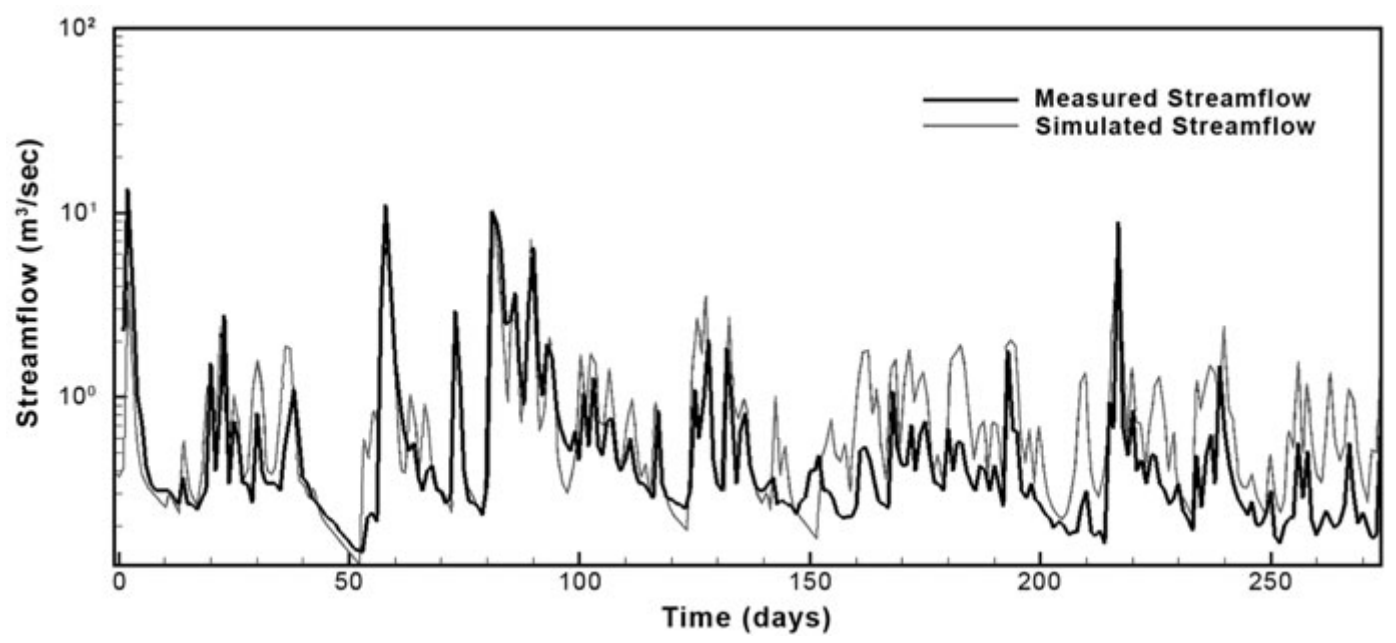

FIGURE 4. Modeling results compared with measurements taken at the Mānoa-Pālolo gauging station, for 1 January30 September 2004.

RESULTS

\section{HEC-1 Calibration}

Suitability for HEC-1 to model Mānoa streamflows was tested through strenuous application of streamflow records for 9 months (1 January through 30 September) in 2004. Available daily-rainfall records for the Lyon Arboretum station were used to define rainfall distribution. Hence, the total rainfall amount for each subbasin was treated as that for a single storm with this defined storm distribution. Numerous runs were performed in calibrating the model using streamflow records available from the U.S. Geological Survey (USGS) (http://hi.water.usgs.gov/) for the Mānoa-Pālolo gauging station (USGS Gauge No. 16247100 [Figure 2]). The procedure started by using the Soil Conservation Service numbers estimated from available soil-type and land-use/cover data. Subbasin rainfall averages were estimated based on records for the Lyon Arboretum station scaled according to the known annual averages for each subbasin. Baseflow parameters were simultaneously adjusted to obtain the best match. Overall, peak time of arrival was accurate, but the model consistently overestimated the stream response. Reducing the Soil Conser- vation Service curve numbers to unrealistic values improved on the peak estimates but negatively affected time for the peaks and runoff duration. The best overall match, shown in Figure 4, was obtained by using the curve numbers without any adjustments (as shown in Table 1) and by using average subbasin rainfall rates as fitting parameters. Table 1 also includes the lag time and the time for concentration for each subbasin. The small values are typical of Hawai'i watersheds.

Figure 5 illustrates measured versus simulated streamflows. Table 2 lists the main statistical parameters for the error, absolute error, and root mean square error, as well as the correlation coefficient. Reasonable correlation exists with a value of 0.68 for the correlation coefficient. However, scattering is large, especially at lower flows, owing to the model's simplicity.

The average calibrated rainfall for each subbasin was consistently lower than the expected value based on total rainfall at the Lyon Arboretum station scaled according to the respective subbasin's annual average ('Table 3). The best-match values ranged between 29 and $114 \mathrm{~cm}$, whereas the expected values ranged between 67 and $267 \mathrm{~cm}$. 


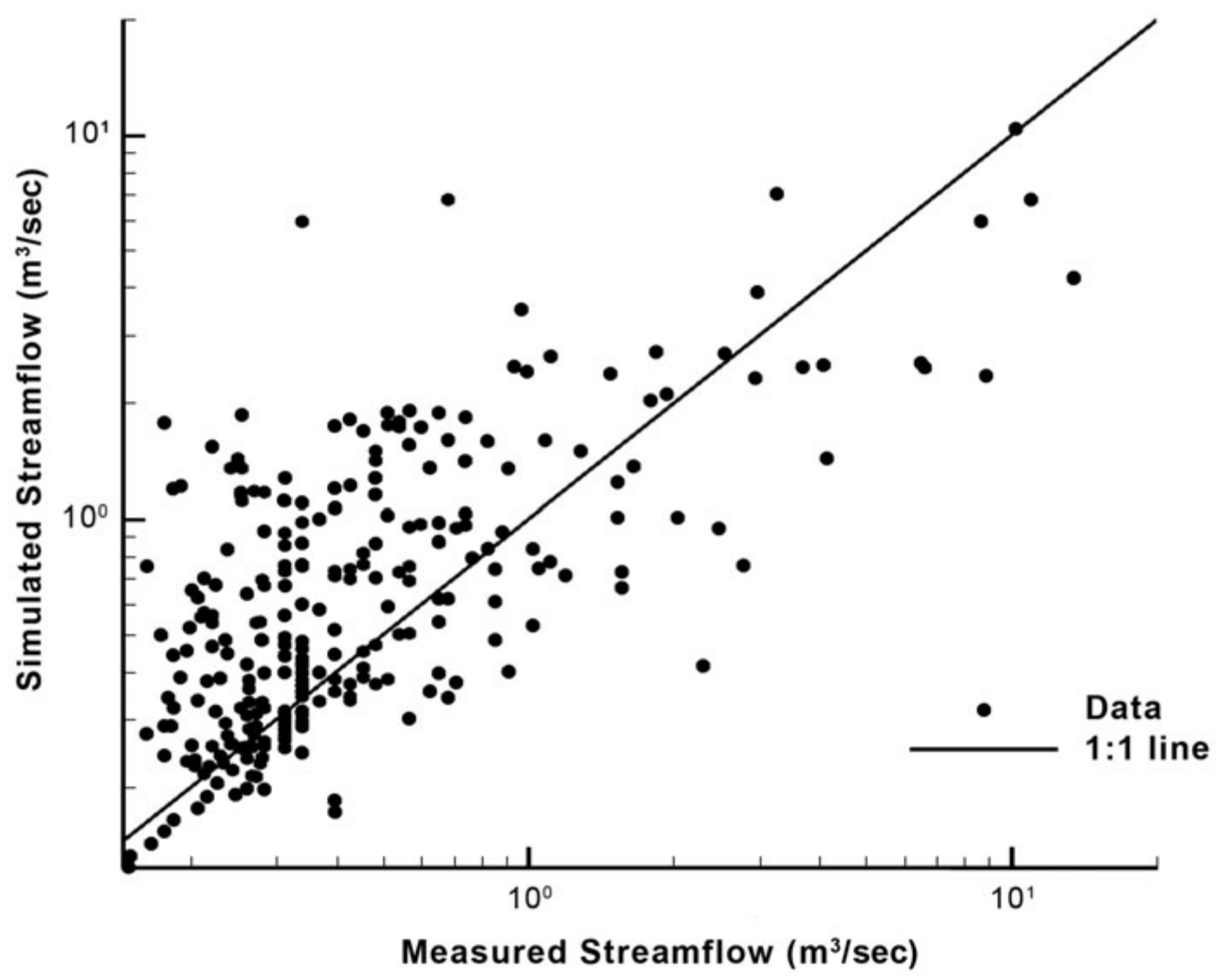

FIGURE 5. Measured versus simulated streamflows for HEC-1 calibration.

Simulations for the October 2004 Storm

Rainfall data for the October 2004 storm at the Lyon Arboretum and the Pālolo Fire Station (K. Kodama, National Weather Service, pers. comm., 2006) were used to define the rainfall time distributions needed for HEC1 . The results showed differences in the temporal variations at the two sites. Storm data were also available (R. Fontaine, pers. comm., 2006) for other gauging stations, including complete streamflow records for the Waiakeakua Stream gauging station (USGS Gauge No. 16240500) and Mānoa-Pālolo gauging station (Figure 2) and partial records for the Lowrey gauging station (Figure 2), which malfunctioned because of the storm.
As was the case for the model calibration discussed earlier, rainfall rates were treated as fitting parameters and no adjustments were made to the Soil Conservation Service curve numbers. Again, the best match occurred at subbasin rainfall amounts that are lower than the expected amounts (Table 3).

Both uncalibrated and calibrated streamflow results are compared with station measurements in Figure 6. Figure 7 illustrates measured versus simulated streamflows for the calibrated and uncalibrated results. Table 2 lists the main statistical parameters for the error, absolute error, and root mean square error, as well as the correlation coefficient. For the two cases, excellent correlation exists with a correlation coefficient of 0.96 . How- 
TABLE 2

Error Analysis Summary for HEC-1 Simulations

\begin{tabular}{|c|c|c|c|c|c|c|c|c|c|c|}
\hline \multirow[b]{2}{*}{ Simulations } & \multicolumn{4}{|c|}{ Error $\left(\mathrm{m}^{3} / \mathrm{sec}\right)$} & \multicolumn{4}{|c|}{ Absolute Error $\left(\mathrm{m}^{3} / \mathrm{sec}\right)$} & \multirow{2}{*}{$\begin{array}{l}\text { Root Mean } \\
\text { Square Error } \\
\left(\mathrm{m}^{3} / \mathrm{sec}\right)\end{array}$} & \multirow[b]{2}{*}{$\begin{array}{l}\text { Correlation } \\
\text { Coefficient }\end{array}$} \\
\hline & Average & Maximum & Minimum & $\begin{array}{l}\text { Standard } \\
\text { Deviation }\end{array}$ & Average & Maximum & Minimum & $\begin{array}{l}\text { Standard } \\
\text { Deviation }\end{array}$ & & \\
\hline HEC- 1 calibration & -0.15 & 9.30 & -6.13 & 1.15 & 0.54 & 9.30 & 0.00 & 1.03 & 1.16 & 0.68 \\
\hline $\begin{array}{c}\text { Waiakeakua Station: } \\
\text { uncalibrated }\end{array}$ & -5.75 & 0.42 & -46.94 & 10.44 & 5.85 & 46.94 & 0.01 & 10.39 & 11.83 & 0.96 \\
\hline $\begin{array}{l}\text { Waiakeakua Station: } \\
\text { calibrated }\end{array}$ & -0.10 & 5.55 & -10.88 & 2.80 & 1.46 & 10.88 & 0.00 & 2.39 & 2.78 & 0.96 \\
\hline
\end{tabular}


TABLE 3

Estimated and Calibrated Total Rainfall Amounts for the Subbasins Shown in Figure 3

\begin{tabular}{|c|c|c|c|c|c|c|}
\hline \multirow[b]{2}{*}{ Subbasin } & \multirow[b]{2}{*}{$\begin{array}{c}\text { Annual } \\
\text { Average }(\mathrm{cm})\end{array}$} & \multirow[b]{2}{*}{$\begin{array}{l}\% \text { of Maximum } \\
\text { Annual Average }\end{array}$} & \multicolumn{2}{|c|}{$\begin{array}{l}\text { Nine-Month Simulation } \\
\text { (HEC-1 Calibration) }\end{array}$} & \multicolumn{2}{|c|}{ October 2004 Simulation } \\
\hline & & & $\begin{array}{l}\text { Estimated } \\
\quad(\mathrm{cm})\end{array}$ & $\begin{array}{l}\text { Calibrated } \\
(\mathrm{cm})\end{array}$ & $\begin{array}{l}\text { Estimated } \\
(\mathrm{cm})\end{array}$ & $\begin{array}{l}\text { Calibrated } \\
\quad(\mathrm{cm})\end{array}$ \\
\hline 1 & 356 & 1.00 & 267 & 114 & 21 & 15 \\
\hline 2 & 330 & 0.93 & 248 & 106 & 19 & 14 \\
\hline 3 & 267 & 0.75 & 200 & 86 & 16 & 11 \\
\hline 4 & 178 & 0.50 & 133 & 57 & 10 & 8 \\
\hline 5 & 152 & 0.43 & 114 & 49 & 9 & 7 \\
\hline 6 & 150 & 0.42 & 112 & 48 & 9 & 6 \\
\hline 7 & 300 & 0.84 & 225 & 96 & 18 & 13 \\
\hline 8 & 300 & 0.84 & 225 & 96 & 18 & 13 \\
\hline 9 & 150 & 0.42 & 112 & 48 & 9 & 6 \\
\hline 10 & 99 & 0.28 & 74 & 32 & 6 & 4 \\
\hline 11 & 94 & 0.26 & 70 & 30 & 6 & 4 \\
\hline 12 & 89 & 0.25 & 67 & 29 & 5 & 4 \\
\hline
\end{tabular}

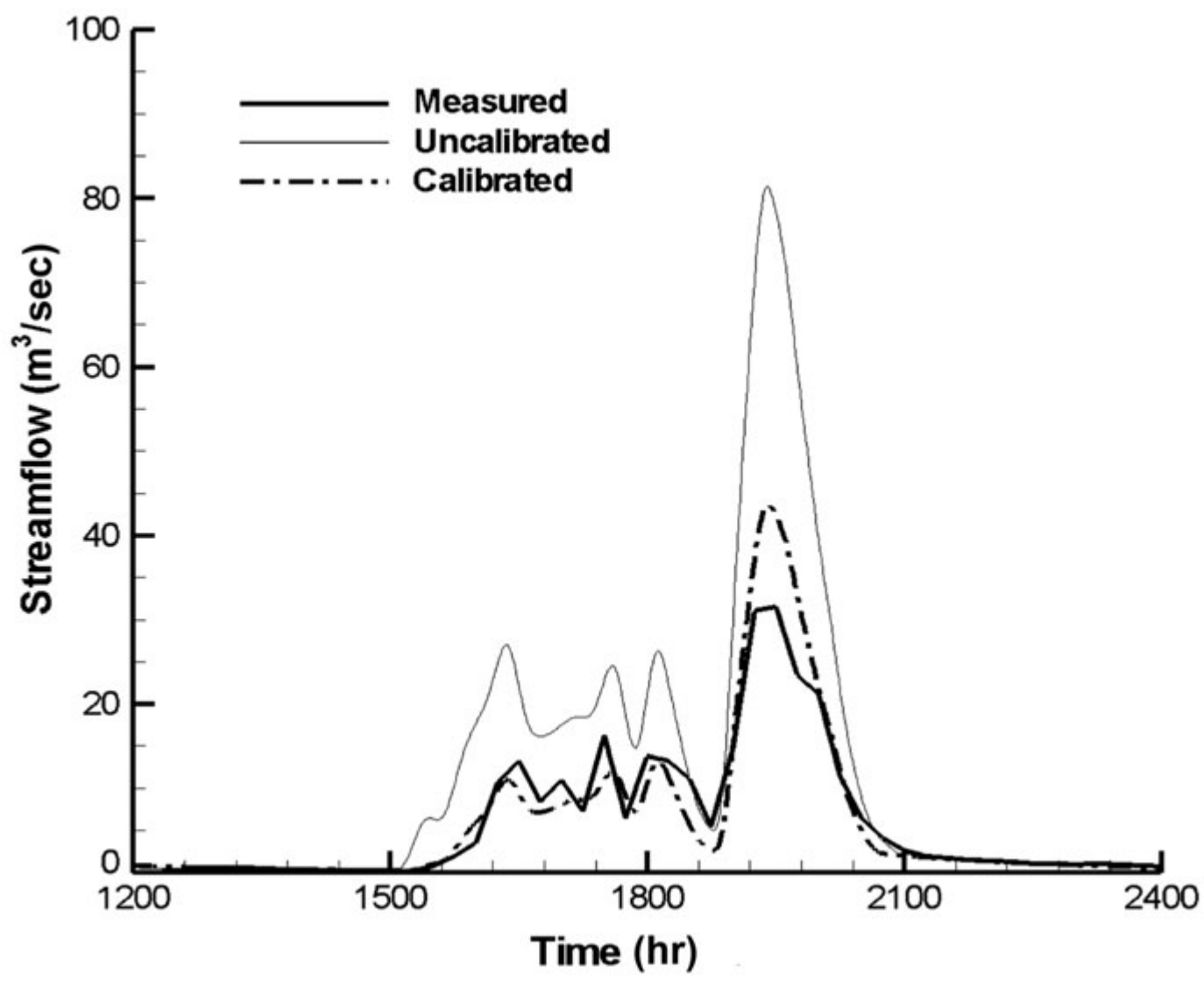

FIgURE 6. Comparison between simulated and available measurements for the 30 October 2004 storm at the Waiakeakua Stream gauging station. 


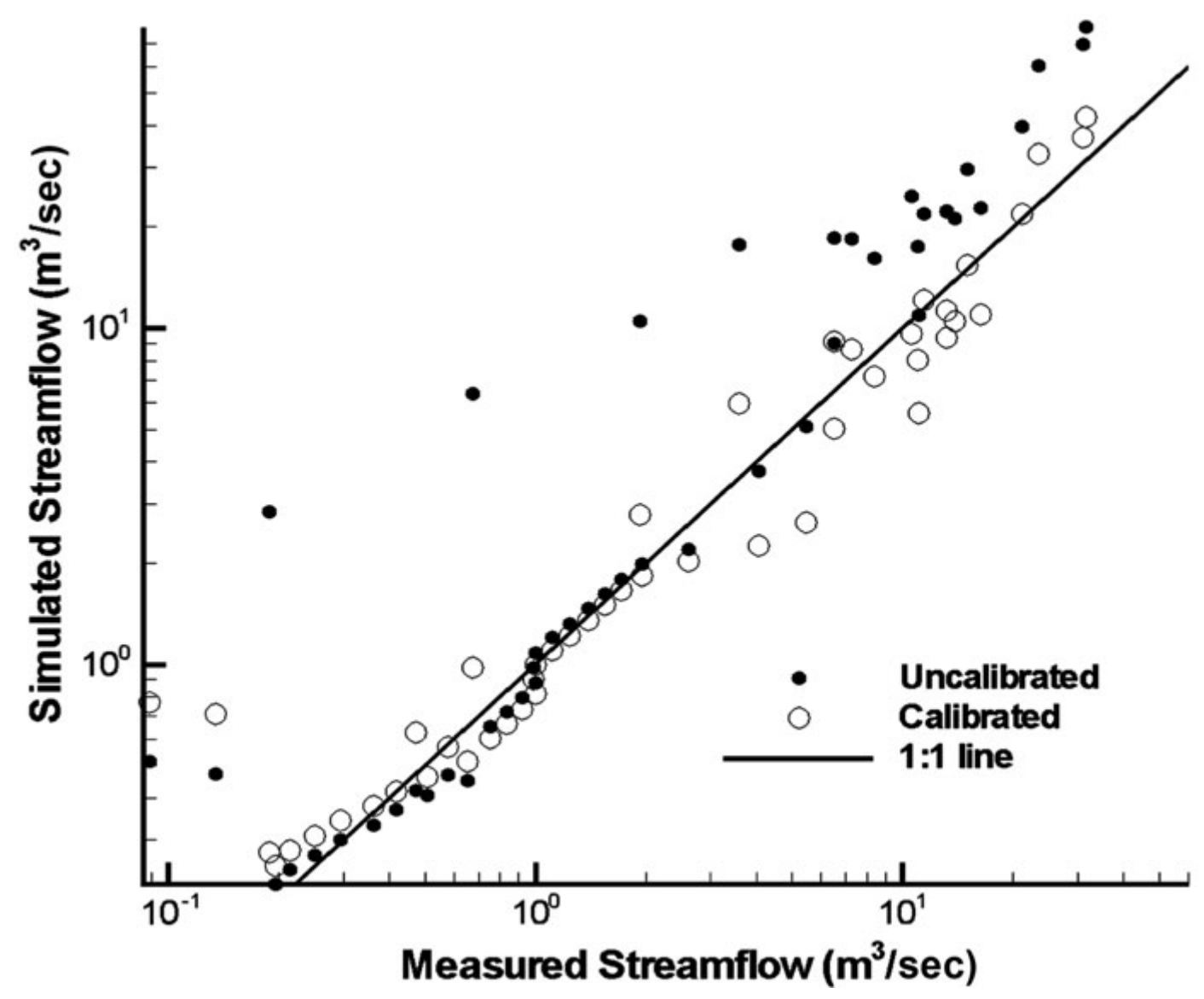

Figure 7. Measured versus simulated streamflows for HEC-1 simulations for the 30 October 2004 storm.

ever, the error and scattering are much smaller for the calibrated case. Plots and error estimates indicate good match between measurements and calibrated results over the whole range of streamflows, including baseflow.

Figure 8 compares simulated streamflow results with available measurements for the Lowrey gauging station. Reasonable match can be seen in the limited range of available measurements. However, it seems that the model overestimates the streamflow after the available records end and when flooding starts to occur, which should be expected considering that floodwaters overflowing the stream banks did not reach the gauging station.
Figure 9 compares simulated streamflow results with available measurements for the Mānoa-Pālolo gauging station. No attempt was made to improve on fitting, considering that the model is expected to overestimate the value of streamflows due to flooding occurring upstream of this site. Floodwaters that left the stream leaked to the West Mānoa Watershed from the Mānoa-Pālolo Watershed.

It can be concluded that HEC-1 is suitable for modeling the study site, considering the nature of the watershed that generates fast and sharp flow hydrographs and quickdeclining baseflows. The Soil Conservation Service curve-number method, which can 


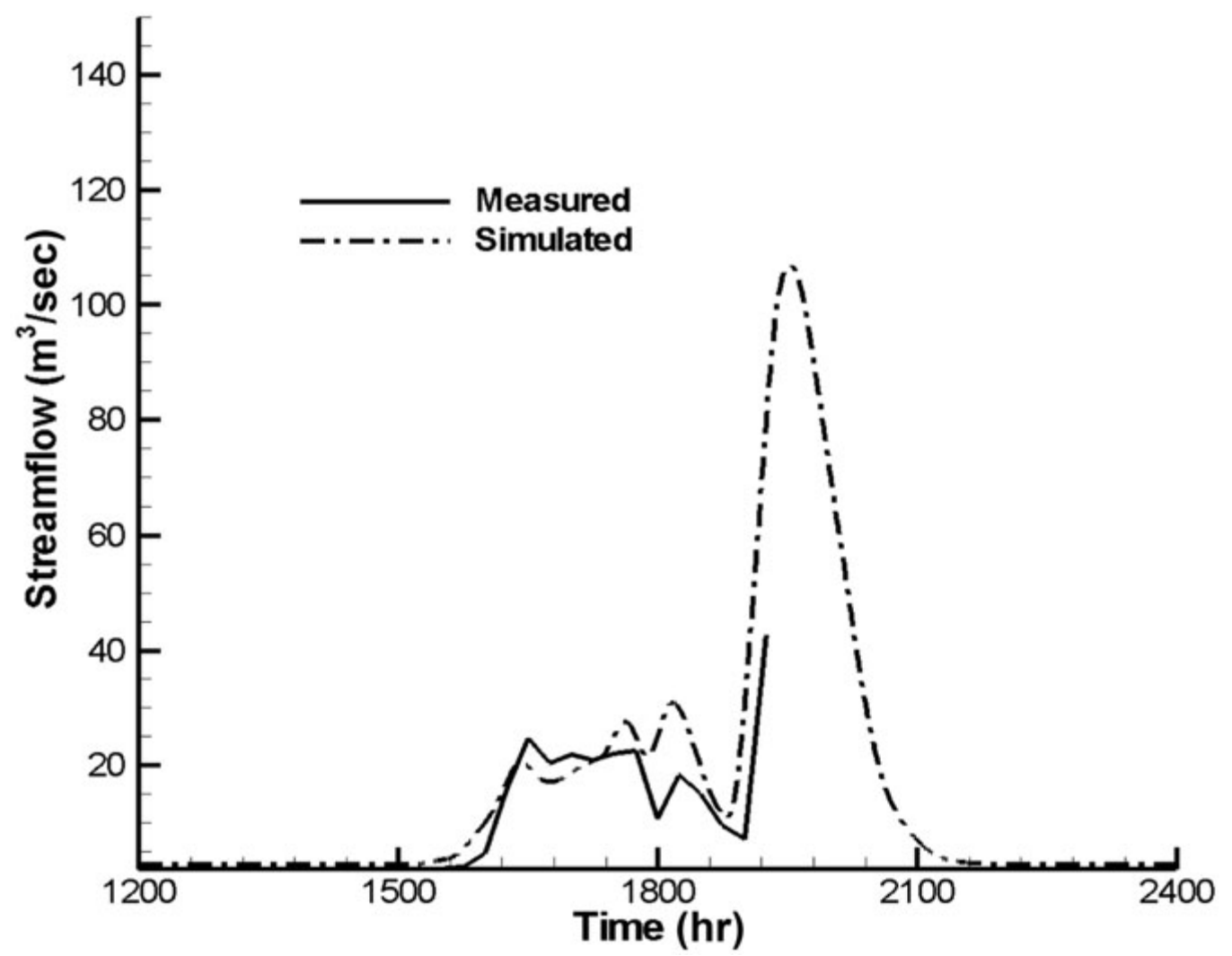

Figure 8. Comparison between simulated and available measurements for the 30 October 2004 storm at the Lowrey gauging station.

produce accurate basin lag time and runoff duration, is also suitable for modeling the study site. No change was necessary for Soil Conservation Service curve-number estimates based on maps of soil type and land use/ cover. However, there is a need for accurate spatial distribution data of rainfall in the area. In addition, a real-time rainfall network is essential to reduce temporal uncertainty in rainfall measurements (e.g., Maskey et al. 2004).

\section{Flood Zone and Levels}

Figure 10 shows the simulated flood delineation areas. The flood zone seems to agree with accounts of flooding during the October 2004 event. Floodwater crossed into the West
Mānoa Watershed in the vicinity of the Woodlawn Bridge and flowed along Woodlawn Drive before following the drainage pathway shown in Figure 10. On the UH campus, damage was caused to the Biomedical Sciences Building, Sherman Laboratory, Hamilton Library, Bilger and Sakamaki Halls, Hawai'i Institute of Geophysics, and the sports complex south of Dole Street, all of which fall within the delineated flood area. Figure 11 shows the simulated maximum flood elevations within the flood zone. Note that these levels do not occur at the same time but at times estimated on the basis of flood wave advancement toward the downstream side. The simulated elevation values are expected to be higher than actual values, considering that the model does not account 


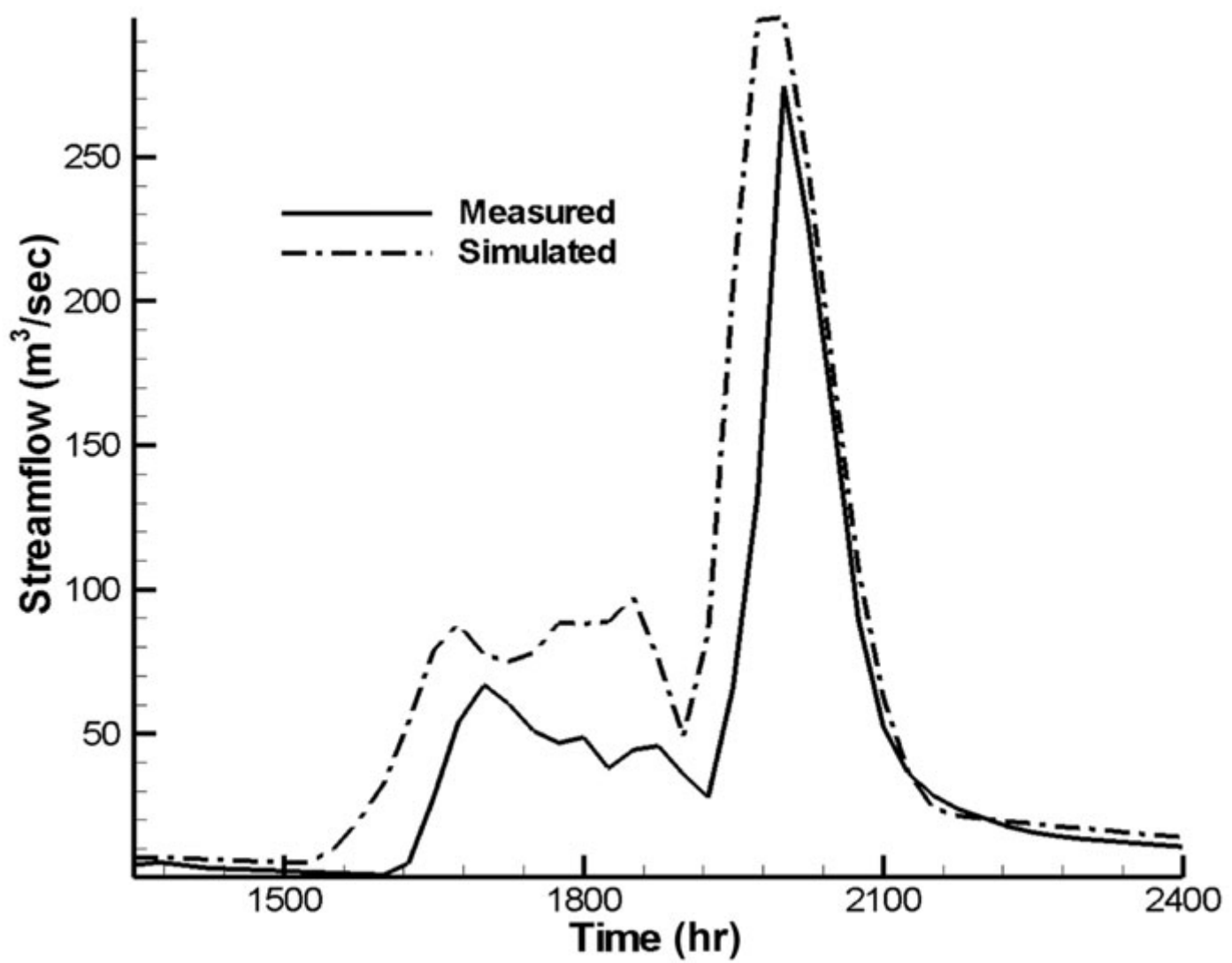

Figure 9. Comparison between simulated and available measurements for the 30 October 2004 storm at the MānoaPālolo gauging station.

for drainage and other water losses, such as to building basements. Validation of these results is not possible due to the absence of field measurements. Still, they are useful as guidelines in assessing potential flooding problems. The model estimated that the maximum flood level around Hamilton Library will be reached $30 \mathrm{~min}$ after the start of the hypothetical dam break-a reasonable estimate considering available news media accounts.

As an example application, a few runs were completed to estimate the maximum flood volume that can occur in the Woodlawn area without affecting the UH campus. An equivalent dam head of about $8 \mathrm{~m}$ was obtained; it yielded a maximum flow rate of $1.213 \times 10^{3}$ $\mathrm{m}^{3} / \mathrm{sec}$ at the dam site and a total flood vol- ume of $4.9 \times 10^{5} \mathrm{~m}^{3}$. An HEC- 1 simulation estimated that a storm with a total rainfall of about $10 \mathrm{~cm}$ and with a similar distribution as that of the 2004 flood would yield such a volume.

\section{Flood Mitigation}

Flood-control options can include stream management practices, such as diversions. One option is to channel part of the flow in Mānoa Stream to the West Mānoa Watershed. An existing pipe system in the watershed opens north of the Biomedical Sciences Building and drains into Mānoa Stream at Dole Street. It is probably feasible to combine stream enhancement in the WoodlawnEast Mānoa area with a drainage system that 


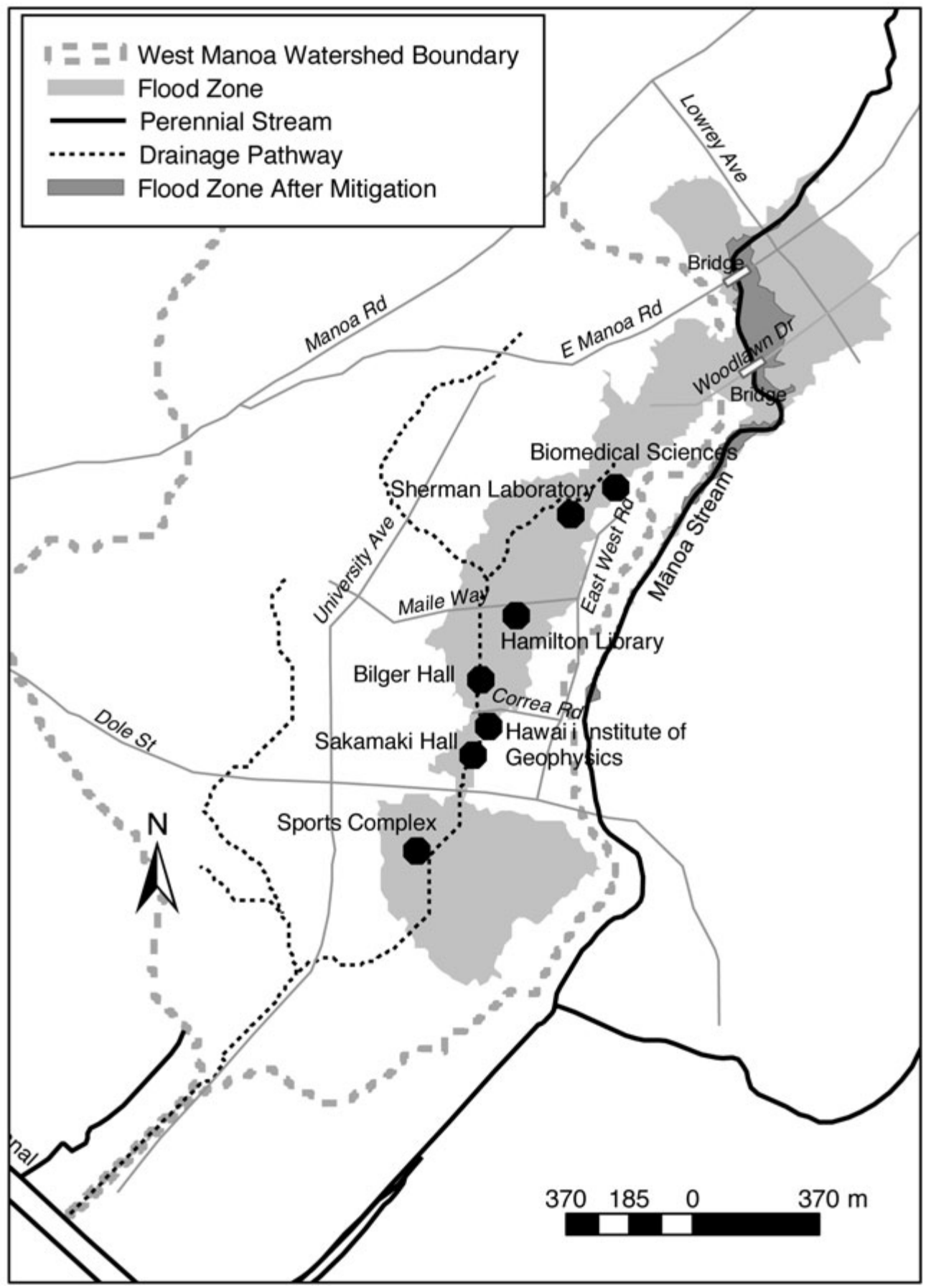

Figure 10. Simulated flood delineation areas for the October 2004 flood. 


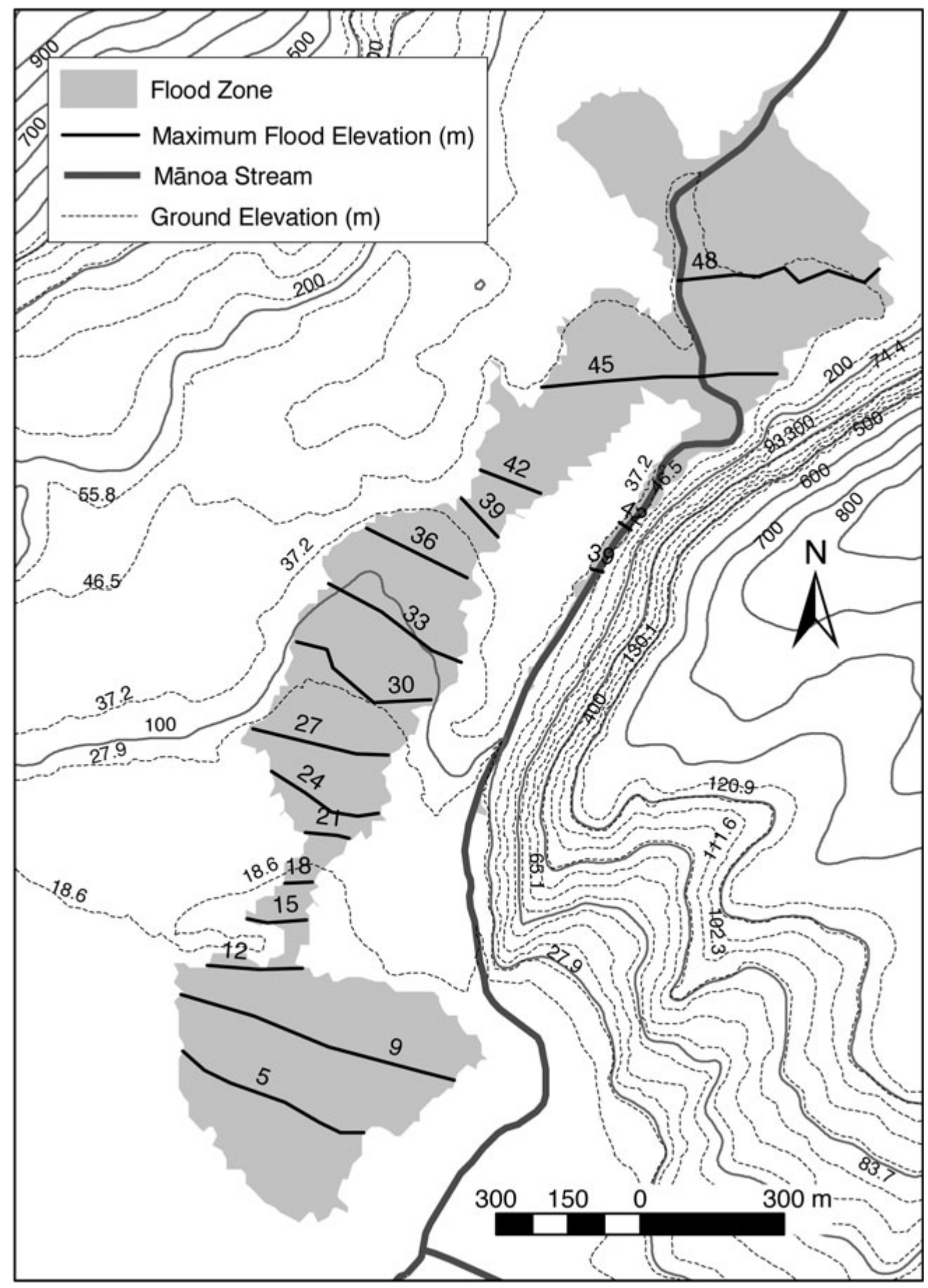

Figure 11. Simulated maximum flood elevations within the flood zone. Note that these levels do not occur at the same time but at times estimated based on flood wave advancement toward the downstream side. 


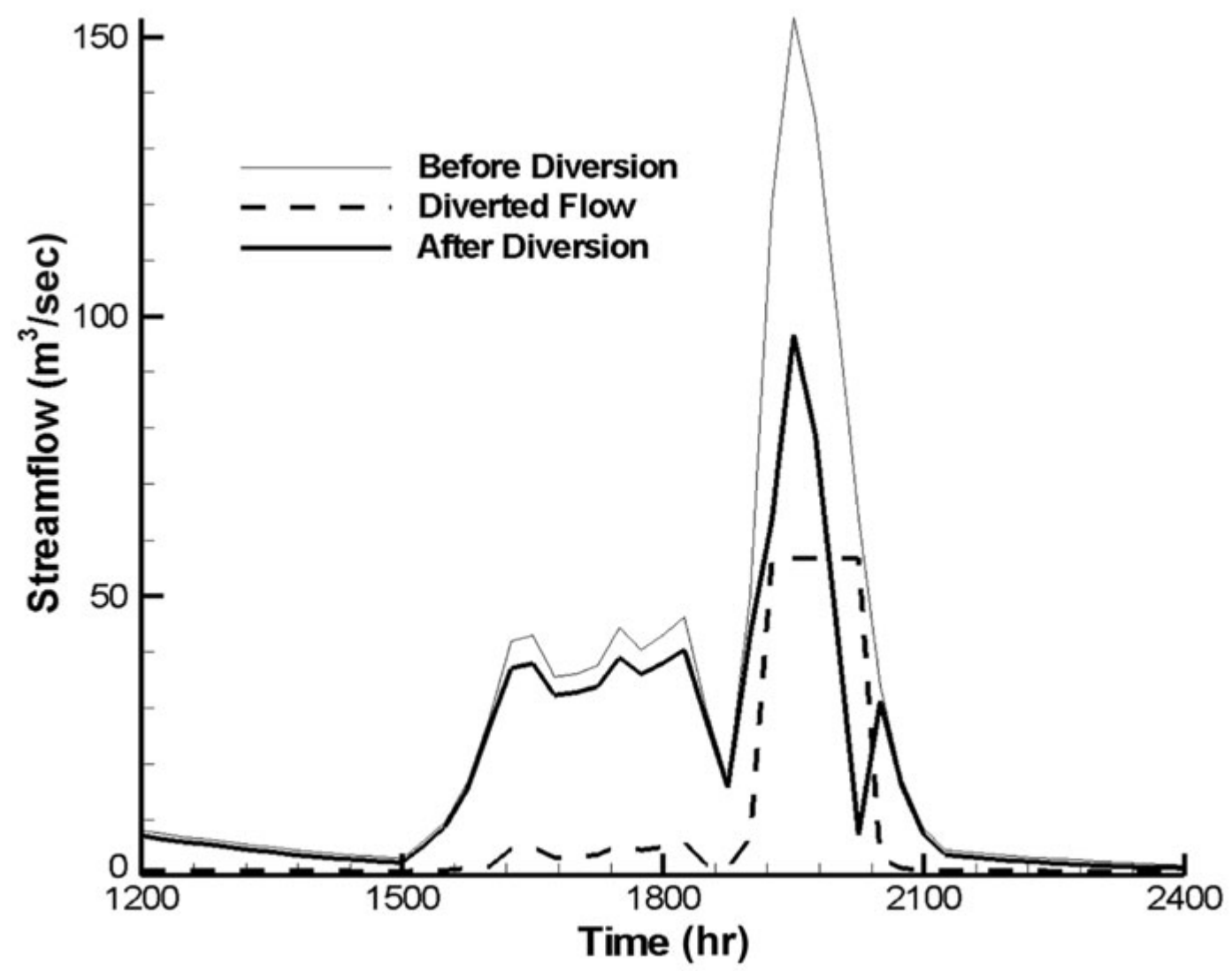

FIgURE 12. HEC-1 results for an assumed diverted flow at a maximum rate of $57 \mathrm{~m}^{3} / \mathrm{sec}$ from Mānoa Stream at the East Mānoa Bridge site to the West Mānoa Watershed.

can channel the flow to a system of pipe drains that can be joined to the existing pipe. Specifics for construction of the drainage basin need to be studied carefully, especially with regard to land use and soil drainage characteristic of the area. Figure 12 shows the HEC-1 results for an assumed diverted flow at a maximum rate of $57 \mathrm{~m}^{3} / \mathrm{sec}$. The peak flow in Mānoa Stream at that section would be reduced from about $150 \mathrm{~m}^{3} / \mathrm{sec}$ to about $93 \mathrm{~m}^{3} / \mathrm{sec}$.

Stream management can also be combined with flood mitigation strategies, including dredging. As an example application of the delineation model, five cross sections along about $1 \mathrm{~km}$ of Mānoa Stream starting at the East Mānoa Street Bridge were edited to simulate improvements, including stream dredg- ing, widening, and realigning. Two examples of edited cross sections are shown in Figure 13. Stream lining can be simulated by adjusting Manning's coefficient such that a smaller value would reflect, for example, the use of concrete lining. Figure 10 shows the simulated flooding zone after implementing the changes. Although the results indicate that it is possible to mitigate the flooding effects, actual implementation of these strategies will mainly depend on availability of land in the vicinity of the stream.

\section{DISCUSSION}

The storm of October 2004 caused extensive damage to the UH campus as well as neighboring residential areas. The unexpected 

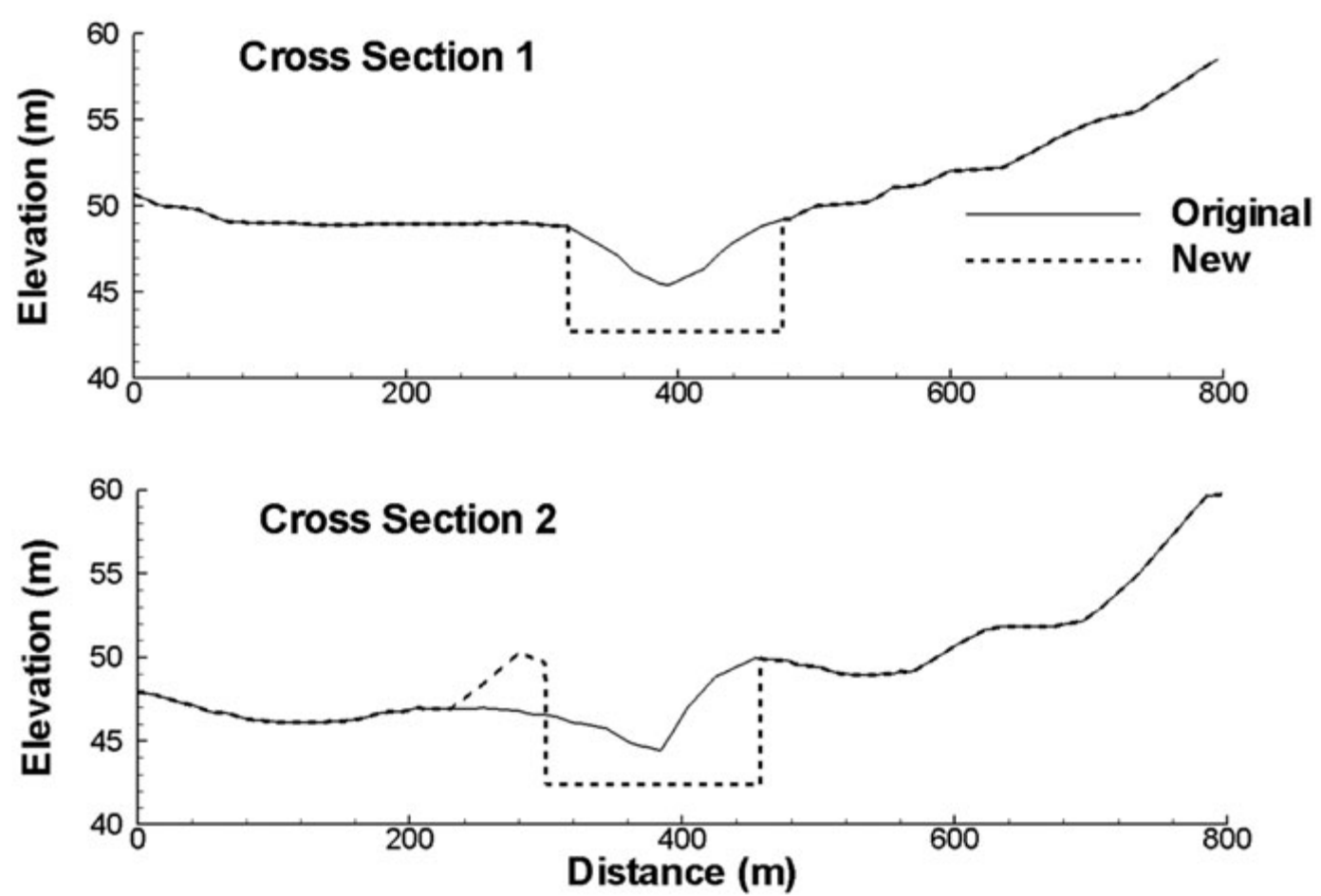

Figure 13. Examples of cross sections that were edited to simulate stream dredging, widening, and realigning. Cross section 1 is near the East Mānoa Street Bridge and cross section 2 is located at the midpoint between that bridge and the Woodlawn Bridge.

damage to the campus revealed a serious lack of data and information about potential flooding in the area. This study used simplified models for streamflow evaluation and flood delineation to investigate the problem. It also examined the usefulness of these models when data are sparse. The study demonstrated that the HEC-1 model of the U.S. Army Corps of Engineers is suitable for streamflow assessment, considering the nature of small Hawai' $i$ watersheds that produce flashy flow hydrographs. The curve-number method of the Soil Conservation Service, based on available maps of land use/cover and soil types, predicts reasonably well the main features of streamflow hydrographs, including runoff duration and time of peaks. Strenuous application of the model using continuous rainfall records over a 9-month period provided reasonable match with available streamflow records. However, the aver- age calibrated rainfall for each subbasin was consistently lower than its expected value. There are several explanations for the discrepancy. The first is related to the simplicity of the HEC-1 model, especially regarding its unsuitability to model continuous rainfall events and the lack of accounting for soil storage. However, the reasonable match of baseflow over the simulated period with a single set of baseflow-fitting parameters is quite remarkable. Such a match is related to the nature of Hawai'i's watersheds, including the rapid response to rainfall storms and the fast decline in baseflow following the storm.

The second explanation is the absence of accurate basinwide rainfall data. Hawai'i rainfall is characterized by high spatial variability, and records for one or two stations will not provide a good representation of rainfall distribution over the entire simulated area. The third potential source of errors is that rainfall 
initial abstraction was not accounted for. Finally, stream records for the gauging stations might not be an accurate reflection of storms, because it is possible that streamflow losses to the West Mānoa Watershed occur, especially during heavy rainfall storms.

Limited data availability precluded the use of the model HEC-RAS (U.S. Army Corps of Engineers 1995) for flood delineations in this study. Rather, a simplified modeling approach was adopted. The onset of floodwater release to the West Mānoa Watershed is treated as a dam break. The main assumptions in this case are (1) water release is treated as a step function of a rectangular hydrograph and (2) at the onset of the flood, the water level at the site of release rises instantaneously to the flood level rather than gradually with the hydrograph rising limb. These assumptions are reasonable for small Hawai'i watersheds, which are characterized by sharp rises and recessions of floodwaters. These assumptions will not drastically influence the delineation of the flood zone because the assumed rectangular hydrograph conserves the volume of water represented by the actual hydrograph. The simplified analysis is likely to introduce an error in the estimation of flood travel time. However, an order of magnitude of such time is available from news media accounts and it can be used for a rough model validation.

The flood delineation model predicted the floodwater pathway and provided estimates of the flood zone, maximum flood depth, and time to reach such a depth. Campus buildings damaged by the flood fall within the delineated flood zone and are very close to the generated drainage pathway, which was developed by using a digital elevation model of the area. The flood delineation model is based on conserving the total streamflow volume and is expected to provide a good estimate of the delineated flood zone. In our simulations, other parameters in the model were treated as fitting parameters; for better results, more data are needed for comprehensive model validation. Yet, for all practical purposes use of such a model is effective as a screening tool in comparing mitigation strategies. The modeling results can help guide the decision- making and data-collection processes. As an example application, the delineation model was used to predict an upper value for storm total flow volume that would not cause flooding on the UH campus. Then HEC-1 was used to predict an upper limit for the value for total rainfall for the storm. Both models were also used to show that it is possible to mitigate the flood through streamflow diversion and stream dredging, realigning, and lining. Sensitivity analyses can be used to define a range of options before collecting appropriate data, thus optimizing data-collection and decision-making processes.

Unfortunately, apart from a general description, no field assessment of the extent of flooding or the respective depth of floodwaters is available. The results of this study should thus be considered as preliminary, and future data collection should be directed toward accurate validation of these results.

We recommend defining a new watershed, the West Mānoa Watershed, containing the university campus for management purposes. Currently, the campus is located within the Ala Wai Watershed, a larger, mostly urbanized area. It seems that flooding problems would only be generated from streamflow leakage from the Mānoa-Pālolo Watershed and not from direct rainfall over the new watershed. Integrating this watershed with the Mānoa Stream basin is not acceptable because under no circumstances would it generate runoff or baseflow to the stream.

Limitations of the models used in this study are related to the accuracy of the digital elevation model. Small-scale changes, such as construction and land-surface changes, are not accounted for. In addition, resolution of the map does not allow accurate assessment in relatively flat ground areas. As typically done, land-use and land-cover characteristics are represented in the models by lumped parameters, such as Manning's coefficients and Soil Conservation Service curve numbers. Accuracy of the model prediction depends on limited knowledge of the spatial resolution of these parameters. Dynamics of water flow as influenced by structures, such as flow and storage in basements, are not included. A higher-resolution model is needed for better 
predictive capabilities. Finally, for simplification purposes, improvements for flood management in some reaches of Mānoa Stream are not included. A justification is that the UH damage was caused by flooding on the Woodlawn area, so consideration of stream improvements elsewhere would minimally affect the modeling results. The current results should represent a worst-case scenario. Future studies can easily include such improvements if detailed data are available.

Further, dynamics of water flow as influenced by structures, such as flow and storage in buildings' basements, are not included. However, inclusion of such dynamics increases the burden of data collection and model development and application.

\section{ACKNOWLEDGMENTS}

We acknowledge the help of Richard Fontaine of the USGS, Honolulu, who provided streamflow data used in this study, and Kevin R. Kodama of the National Weather Service, Honolulu Forecast Office, who provided rainfall data. Comments and suggestions for improvements by an anonymous reviewer are very much appreciated. Some of the USGS data are provisional and may be subject to revision.

\section{Literature Cited}

Fread, D. L. 1988. DAMBRK-The NWS dam-break flood forecasting model. National Weather Service, Silver Spring, Maryland.

Hawai'i Department of Land and Natural Resources. 1992. A management plan for the Ala Wai Canal watershed. Department of Land and Natural Resources, Division of Water and Land Development, Honolulu, Hawai'i.

1995. A study to alleviate flooding of Mānoa Stream (East Mānoa Road to Woodlawn Drive) island of Oahu. Department of Land and Natural Resources, Division of Water and Land Development, Honolulu, Hawai'i.

Martín-Vide, J. P., D. Niñerola, A. Bateman, A. Navarro, and E. Velasco. 1999. Runoff and sediment transport in a torrential ephemeral stream of the Mediterranean coast. J. Hydrol. 225:118-129.

Maskey, S., V. Guinot, and R. K. Price. 2004. Treatment of precipitation uncertainty in rainfall-runoff modelling: A fuzzy set approach. Adv. Water Resour. 27:889-898.

Muzik, I. 2002. A first-order analysis of the climate change effect on flood frequencies in a subalpine watershed by means of a hydrological rainfall-runoff model. J. Hydrol. 267:65-73.

Smith, D. P., and P. B. Bedient. 1981. Preliminary model of an urban floodplain under changing land use. J. Hydrol. 51:179185.

Soil Conservation Service. 1972. National engineering handbook, section 4. U.S. Department of Agriculture, Washington, D.C.

. 1975. Urban hydrology for small watersheds. Technical Release No. 55. U.S. Department of Agriculture, Washington, D.C.

Townscape, Inc., and Eugene P. Dashiell, AICP in cooperation with Oceanit. 2003. Ala Wai Watershed Analysis, Final Report. Department of Land and Natural Resources and U.S. Army Corps of Engineers, Honolulu.

U.S. Army Corps of Engineers. 1995. HECRAS, River analysis system, Hydraulics reference manual. Hydrologic Engineering Center, Davis, California.

- 1998. HEC-1 flood hydrograph package. User's manual. Hydrologic Engineering Center, Davis, California.

Warner, J., G. V. Loganathan, R. J. Kane, M. Gillen, D. F. Kibler, and K. Kostura. 1996. The Timberlake Dam failure: A hydrometeorological assessment. Proc. North American Water and Environment Congress and Destructive Water. American Society of Civil Engineers, Reston, Virginia.

Wetmore, J. N., and D. L. Fread. 1981. The NWS simplified dam-break flood forecasting model. National Weather Service, Silver Spring, Maryland.

Wurbs, R. A. 1987. Dam-breach flood wave models. J. Hydraul. Eng. 113 (1): 29-46. 
